\title{
The Relationship between the Factors and Conditions of the Autonomy of Preschool Teachers and Fostering the Autonomy of Preschool Children in Kindergarten
}

Tatjana DevjaK ${ }^{* 1}$, Irena JanžeKovič ŽMauC ${ }^{2}$ AND Jože Benčina ${ }^{3}$

$\approx$ In the paper, we argue that fostering the autonomy of children in kindergarten contributes to the positive effects of the individual's autonomy later in life. Various sources substantiate the assumption that there is a relationship between the child's autonomy and the autonomy of educators. In the paper, we identify and investigate how preschool teachers evaluate the factors of their own professional autonomy, we determine the factors and conditions that, in their opinion, foster the autonomy of preschool children, and we verify whether the assessment of both factors and conditions affects the actual state of the stimulation of the autonomy of children in kindergarten. With regard to fostering the autonomy of children, we have in mind the participation of children, enabling them to play and learn and to manipulate materials and teaching aids in their own way, so that preschool teachers can offer them a choice, take into account their feelings and perspectives, and provide them with rational feedback. The results of the research show that an evaluation of the factors and conditions for fostering the autonomy of children by preschool teachers $(\mathrm{N}=524)$ has a beneficial effect on fostering the autonomy of the children, but it is not crucial. The most important factors in fostering the autonomy of children are the preschool teacher as a person and the participation of children.

Keywords: preschool teacher, preschool children, autonomy, factors of autonomy, fostering the autonomy of children

$1 \quad{ }^{*}$ Corresponding author. Faculty of Education, University of Ljubljana, Slovenia; tatjana.devjak@pef.uni-lj.si.

2 Slovenian Traffic Safety Agency, Slovenia.

3 Faculty of Administration, University of Ljubljana, Slovenia. 


\section{Razmerje med dejavniki in pogoji avtonomije vzgojiteljev in spodbujanje avtonomije predšolskih otrok v vrtcu}

TATJANA DevjaK, Irena JanŽEKovič ŽMaUc IN JožE BenČINA

$\propto$ Avtorji v prispevku zagovarjajo tezo, da spodbujanje avtonomije otrok $\mathrm{v}$ vrtcu prispeva k pozitivnim učinkom avtonomije posameznika v poznejšem obdobju. Različni viri utemeljujejo predpostavko, da obstaja razmerje med avtonomijo otrok in avtonomijo vzgojiteljev. V prispevku so avtorji ugotavljali in raziskovali, kako vzgojiteljice in vzgojitelji vrednotijo dejavnike lastne strokovne avtonomije, dejavnike in pogoje, ki po njihovem mnenju spodbujajo avtonomijo predšolskih otrok, ter ali ocena obojih dejavnikov in pogojev vpliva na dejansko stanje spodbujanja avtonomije otrok v vrtcu. Ko govorimo o spodbujanju avtonomije otrok, imamo v mislih participacijo otrok, omogočanje možnosti otrokom, da se igrajo in učijo ter manipulirajo z materiali, učnimi pripomočki na svoj način, da vzgojitelji in vzgojiteljice nudijo otrokom možnost izbire, upoštevajo njihova čustva in perspektivo otrok ter jim dajejo racionalne povratne informacije. Izsledki raziskave kažejo, da vrednotenje vzgojiteljic in vzgojiteljev $(\mathrm{N}=524)$ dejavnikov in pogojev spodbujanja avtonomije otrok ugodno vpliva na spodbujanja avtonomije pri otrocih, ni pa ključnega pomena. Najpomembnejša dejavnika spodbujanja avtonomije otrok sta vzgojitelj kot oseba in participacija otrok.

Ključne besede: vzgojitelji, predšolski otrok, avtonomija, dejavniki avtonomije vzgojiteljev, dejavniki spodbujanja avtonomije otrok 


\section{Introduction}

In modern democratic societies, autonomy is one of the most important organisational principles of the public education system. The importance of the autonomy of professionals in education is connected to monitoring and quality assurance in the field of education. Increasing the autonomy of schools and kindergartens is one of the main trends in every modern education policy. The quality of preschool education is not only important for the autonomy of preschool teachers, but also for fostering autonomy in children. The preschool teacher's conception and the fostering of autonomy in children should be connected, while also being a condition for more independent behaviour in children, developing competence in their behaviour, and attaining higher achievements.

The main aim of the research is to determine whether the actual fostering of autonomy in children is affected by the importance given to the factors of the autonomy of preschool teachers and to the factors and conditions of fostering the autonomy of children. The findings of previous research already show that the autonomy of preschool teachers is a prerequisite for fostering autonomy in children. We assume that the factors of the autonomy preschool teachers and the factors and conditions of children's autonomy affect the actual autonomy of children. The actual autonomy of children and preschool teachers' autonomy are interdependent, occurring simultaneously and reinforcing each other. The preschool teacher plays the most important role in fostering the autonomy of the child, as he or she autonomously decides on the work, activities, goals and rules in the playroom. If preschool teachers want to foster children's autonomy, they must "start with themselves" (Pelletier Sequine-Levesque \& Legault, 2002). The more autonomous preschool teachers feel at work, the more they foster the development and autonomy of children and their participation (Woolfolk \& Hoy, 1990).

Autonomy as a concept means independent decision-making; at the same time, it is an instrument for exercising powers. If we proceed from morality and philosophy, we can consider it as the basis for determining the responsibility of the individual for his or her own actions. Therefore, "the need for the professional development of the teaching profession arises constantly and is deemed to be a tool for helping teachers cope with the challenges of their teaching practices in a post-modern reality" (Vula et al., 2015, p. 112). Krek and Metljak (2011) $)^{4}$ emphasise the importance of the autonomy of professional workers and the autonomy of educational institutions, linking it with monitoring and

4 In the White Paper on Education in the Republic of Slovenia (2011, pp. 13-14), the principle of autonomy was defined by Krek et al. 
quality assurance in the field of the work of school. The autonomy of preschool teachers is provided by predefined frameworks within which preschool teachers have the possibility of freedom in their work (ibid.) Some authors (Logaj, 2012; Trnavčevič \& Zupanc Grom, 2000) associate autonomy with the development of markets (private offers) in education and with the development of the deregulation of the system. Others (Koren, 2006; Marentič Požarnik et al., 2005) understand autonomy as a guiding principle and a working condition, including professionalism, space, individuals, the local environment and legal provisions. Autonomy is not just a synonym for independence; it must also be understood as a principle of social relations. The concept of autonomy is derived from an autonomous individual and autonomous behaviour. Logaj (2012) explains the boundary conditions of autonomy, the interaction between autonomy and responsibility associated with decentralisation, that is, in response to the question of what the aims of education are and who pursues them. Autonomy is therefore always limited and requires the responsibility of its actors.

The reason for the worldwide commitment to autonomy in kindergartens and school systems is the understanding of autonomy as a quality condition (Eurydice, 2008; Iftene, 2014; Koren, 2002; Zupančič, 2013). One of the aims of the Slovenian Curriculum for Kindergartens is greater autonomy and professional responsibility of professionals and kindergartens (Curriculum for Kindergartens, 1999). Some authors associate autonomy with the decentralisation of the school system, with the level of freedom, responsibility and control represented by the school inspectorate, superiors, the environment and legal regulations, while others perceive it as the relationship between kindergarten, school and preschool teachers; still others understand the autonomy of preschool teachers as freedom in decision-making and the selection of teaching methods, the design of work content and tasks, the choice of materials and the creation of didactic aids, and assuming responsibility by linking with the work in the educational process in kindergarten (Parrott \& Da Ros-Voseles, 2013; Tehrani \& Mansor, 2012).

Thavenius (1999) argues that the autonomy of children and the autonomy of preschool teachers occur at the same time and are mutually reinforcing, as the pedagogical professional must work autonomously with the participants in the educational process and the learning process (ibid.). According to Smith (2001), this means: 1) independent professional action, a participatory relationship with the child in professional action, and the cancellation of traditional supervision of the educational process; 2) the ability of independent professional action; 3) an absence of supervision in professional action; 4) independent professional development and the ability for independent professional 
development; and 5) absence of supervision over professional development (ibid.). If we draw from the individual views of the authors described above, the autonomy of preschool teachers and teachers in the process of education is possible only within institutional rules and curricula, so that the child/pupil takes control of legitimate arrangements. From the point of view of the child/ pupil, however, autonomy primarily refers to the learning process, and more generally to his or her attitude towards life outside the classroom (Masouleh \& Jooneghani, 2012).

The key conditions for preschool teachers' autonomy and responsibility are: a high level of knowledge, a willingness to critically handle new information, an ability to make decisions in a particular context, and rational thinking, which includes an ability to identify problems and create solutions based on analysed evidence (Castle, 2006; Kalin, 2002; Rutar Ilc, 1999). The preschools teacher's task is to "respect the child's or pupil's freedom, creativity and spontaneity" (Tašner et al., 2017, p. 52). From the children's point of view, the key condition for fostering autonomy in children is fulfilled when the preschool teacher provides a competence-support structure, which means leadership that is sensitive to the problems and wishes of the children (Vansteenkiste et al., 2012). The first factor in fostering the autonomy of children in kindergarten is the preschool teacher ${ }^{5}$ (Hardre \& Reeve, 2003; Kroflič, 2001; Reeve et al., 2004; Su \& Reeve, 2011), his or her education (Castle, 2004; Parrott \& Da Ros-Voseles, 2013), and his or her attitude and readiness for proper thinking and behaviour (Little, 2002). The ability to create the conditions for the development of autonomy in children at preschool age can have a long-term effect. Preschool teachers who have had an opportunity to study in programmes based on constructivism (own reflection and building knowledge based on experience for best practice) put the child's autonomy at the forefront. Not only the kindergarten culture, but also the wider social culture has an impact on fostering autonomy in children. Culture influences three dimensions of fostering autonomy: thinking, fostering autonomous decision-making, and fostering psychic separation (from adults) (Manzi et al., 2012).

Preschool teachers can foster the autonomy of children by respecting children's opinions and ideas, by giving them choices, by encouraging them to explore their interests, and by explaining the importance of the learning activities (Skinner \& Belmont, 1993; Tucker et al., 2002; Wellborn et al., 1992). This way, children "can learn and implement techniques for idea production, such as brainstorming

5 Preschool teachers are one of the main conditions for fostering the autonomy of children. They are considered to have a key role because they are influenced by many factors (social context and culture, the personality traits and beliefs of the preschool teacher, the professional knowledge and attitude of preschool teachers, their ability to empathise and communicate, legislation, etc.) that must be fulfilled to encourage the autonomy of children. 
and techniques for stimulating lateral thinking, so that work on the development and production of ideas is not limited to the unconscious level" (Vuk et al., 2015, p. 56). Preschool teachers can foster the autonomy of children by asking for their opinion and then taking that opinion into account. Mooney and Blackburn (2002) believe that, if we ask children for their opinion and then fail to take that opinion into account, we convey the message to children that we in fact have little interest in knowing their view, which can have long-term consequences for their willingness to later engage as adult citizens. The more preschool teachers feel effective in their work, the more they encourage the development and autonomy of children and their cooperation (Woolfolk \& Hoy, 1990).

Encouraging children's autonomy refers to the degree of freedom that the preschool teacher allows children, the preschool teacher's encouragement of children's self-initiative and decision-making, and the preschool teacher's ability to share the child's perspective in solving problems or providing advice (Reeve, 1998). Fostering the autonomy of children means listening and accepting the child's opinion, which requires the preschool teacher to provide secure communication, to encourage children to share their thoughts, opinions, suggestions and views, to listen carefully and respond, and to take into account and accept the negative feelings of children (Reeve, 2006). Preschool teachers should offer children advice and information when they are stuck in a task, thus encouraging and motivating them to continue the task (Grolnick, 2001). In addition, they should provide children with opportunities to make choices, understand and trust their abilities, encourage them to ask questions and think, etc. (Williams \& Deci, 1996).

\section{Method}

Research shows that the level of the factors of the autonomy preschool teachers, as well as the factors and conditions for fostering the autonomy of children, affect the autonomy of children. ${ }^{6}$ In different environments, the levels of autonomy can vary, so we established the following hypothesis in order to verify the impact:

H: The factors of preschool teachers' autonomy and the factors and conditions for fostering the autonomy of children (as assessed by preschool teachers) affect the actual autonomy of children. The hypothesis was dealt with by means of three sub-hypotheses: (1) Ha: The factors of preschool teachers' autonomy influence the actual fostering of children's

6 Findings by Skinner \& Belmont, 1993; Tucker et al., 2002; Hardre \& Reeve, 2003; Su \& Reeve, 2011 and Parrott \& Da Ros-Voseles, 2013 are described in the theoretical introduction. 
autonomy; (2) $\mathrm{Hb}$ : The factors of fostering the autonomy of children affect the actual fostering of children's autonomy; (3) Hc: The conditions for fostering the autonomy of children affect the actual fostering of children's autonomy.

The hypotheses were verified by means of a regression model in which the dimensions (factors) of the factors of preschool teachers' autonomy and the factors and conditions for fostering the autonomy of children appear as predictive variables, while the response variable is a one-dimensional construct of an assessment of the actual state of children's autonomy. The model variables were determined by means of exploratory factor analysis (principal component analysis with varimax rotation) for each of the considered concepts.

The data were analysed using the SPSS Statistical Processing Program. The IBM SPSS Statistics 25 statistical package was used at the level of descriptive statistics, dimensional reduction and regression modelling. For assessment of the normality of distributions, the values for asymmetry and kurtosis between -2 and +2 were considered (George \& Mallery, 2010).

In research conducted in the spring of 2016,7 163 randomly selected Slovenian public kindergartens were included. The target population of the research was preschool teachers and preschool children in the Republic of Slovenia. The obtained sample included 524 preschool teachers, representing $10.13 \%$ of all preschool teachers in public kindergartens in the Republic of Slovenia (Statistical Office of the Republic of Slovenia, 2016).

After examining the research data, we moved to the definition of the variables of the regression model. The steps of exploratory factor analysis were carried out using principal component analysis with varimax rotation. First, some variables with a low-value of communalities were eliminated (one variable in the factors of preschool teachers' autonomy and the factors fostering the autonomy of children, and two variables in the conditions for fostering the autonomy of children). Next, we acquired three factors for the factor of preschool teachers' autonomy, four factors for the factor of fostering the autonomy of children, two factors for the conditions of fostering the autonomy of children, and a uniform factor for assessing the state of children's autonomy. Finally, we confirmed the appropriateness of the characteristics of the factor model. For all four models, the Cronbach alpha is greater or equal to $.685(.852, .848, .685$, .811 ), the Kaiser-Meyer-Olkin measure of sampling adequacy is greater than or equal to $0.812(.812, .851, .849$ and .816$)$, and the statistical feature of Bartlett's test of sphericity is equal to .ooo.

7 The descriptive and causal-non-experimental method of pedagogical research was used. 


\section{Interpretation of results}

\section{Factors of autonomy of preschool children}

The positive attitude of preschool teachers towards their work is one of the factors of their autonomy. Slovenian preschool teachers judge that their own autonomy is comprised of their responsibility, professionalism and competence, the possibility of making decisions and choices, planning (group work, goals, etc.), creativity, decision-making and selection, defending their positions, developing knowledge and education, and independence.

Different factors influence preschool teachers' autonomy. We have examined how the factors and their influence are perceived and evaluated by preschool teachers themselves.

\section{Table 1}

Factors of preschool teachers' autonomy

\begin{tabular}{|c|c|c|c|c|c|c|c|c|c|}
\hline & Factors of autonomy & $\mathrm{N}$ & Min & Max & M & $\mathrm{R}$ & SD & SK & $\mathrm{K}$ \\
\hline f & $\begin{array}{l}\text { Preschool teacher's positive attitude towards } \\
\text { work }\end{array}$ & 524 & 1 & 5 & 4.76 & 1 & .62 & -3.73 & 17.42 \\
\hline$d$ & Satisfaction with work & 524 & 1 & 5 & 4.63 & 2 & .70 & -2.52 & 8.11 \\
\hline b & Skills of educators & 524 & 1 & 5 & 4.62 & 3 & .69 & -2.40 & 7.80 \\
\hline $\mathrm{h}$ & Climate & 524 & 1 & 5 & 4.45 & 4 & .72 & -1.07 & .27 \\
\hline e & Working conditions & 524 & 1 & 5 & 4.43 & 5 & .83 & -1.57 & 2.54 \\
\hline k & Cooperation with parents & 524 & 1 & 5 & 4.14 & 6 & .94 & -1.20 & 1.43 \\
\hline g & Dynamics & 524 & 1 & 5 & 4.07 & 7.5 & 1.00 & -1.01 & .48 \\
\hline j & Management of kindergarten & 524 & 1 & 5 & 4.07 & 7.5 & .86 & -.71 & .18 \\
\hline c & Subjective theories & 524 & 1 & 5 & 3.71 & 9.5 & 1.11 & -.78 & .05 \\
\hline i & Regulations & 524 & 1 & 5 & 3.71 & 9.5 & .96 & -.37 & -.25 \\
\hline a & National culture & 524 & 1 & 5 & 3.12 & 11 & 1.16 & -.36 & -.59 \\
\hline I & $\begin{array}{l}\text { Independence of preschool teachers from } \\
\text { support }\end{array}$ & 524 & 1 & 5 & 2.22 & 12 & 1.09 & .82 & .22 \\
\hline
\end{tabular}

All 524 of the preschool teachers surveyed agreed that these factors influence the autonomy of preschool teachers. According to a 5-point scale from 1 to 5 , the preschool teachers strongly agreed that a positive attitude towards work is a factor of preschool teachers' autonomy $(M=4.76)$. This factor also displayed the lowest standard deviation $(S D=.62)$, while rather high values of asymmetry and kurtosis $(S K=-3.73$ and $K=17.42)$ indicated a greater number of higher values. A positive attitude towards work (Erden, 1995; Gürsoy, 2016) is 
a factor in preschool teachers' autonomy, as it contributes to the behaviour and motivation of individuals. Satisfaction with work, together with reflection on one's own practice, gives preschool teachers self-confidence (Noormohammadi, 2014) when planning work. The competence, professional knowledge and good skills of preschool teachers contribute to the realisation of their own autonomy (Öztürk, 2012); together with subjective theories and beliefs about professional competence, these are a factor in preschool teachers' autonomy (Kroflič et al., 2002). National culture is also an important factor in preschool teachers' autonomy (Benson, 2001), as the belief of society regarding the permitted extent of preschool teachers' autonomy is a precondition to that autonomy. It is regulations (Curriculum 1999; ZVrt, 2005; ZOFVi, 2006; White Paper, 2011) that determine the autonomy of preschool teachers at the implementation level. The support of management, as well as the good working conditions and positive climate of the kindergarten, contribute to preschool teachers' autonomy and the realisation of that autonomy (Meng \& Ma, 2015; Usma Wilches, 2009).

The autonomy and independence of preschool teachers from the support of colleagues and external pressures (Zgaga, 1990) is a factor in preschool teachers' autonomy. In a free answer about the key factors of autonomy, 57.6\% of the preschool teachers surveyed agreed that their autonomy is influenced by various factors, but above all depends on their professional competence and professional development (continuous professional education, self-confidence, decision-making and assuming responsibility, attitude towards work, working conditions, etc.), as well as on the personality of the individual preschool teacher and his or her pedagogical Eros. Smaller proportions of the respondents also highlighted the factors of support from management, the continuous professional education and lifelong learning of preschool teachers, the positive attitude of preschool teachers (towards work, children, etc.), good self-image, the working conditions and good climate in the kindergarten, satisfaction (with work, with the profession, with themselves), and the possibility of making decisions and assuming responsibility. Only $1.15 \%$ of the preschool teachers found it crucial that preschool teachers themselves could contribute to their professional autonomy.

\section{Factors that influence the fostering of children's autonomy}

In order to foster the autonomy of children, several factors are needed, the key factor being the preschool teacher and his or her way of working. In Table 2, we present the respondents' evaluation of factors that influence fostering the autonomy of preschool children. 


\section{Table 2}

Factors of fostering the autonomy of children, in the opinion of preschool teachers

\begin{tabular}{|c|c|c|c|c|c|c|c|c|c|}
\hline & Factors of autonomy & $\mathrm{N}$ & Min & Max & M & $\mathbf{R}$ & SD & SK & K \\
\hline C & $\begin{array}{l}\text { Preschool teachers' positive attitude towards } \\
\text { fostering the autonomy of children }\end{array}$ & 524 & 3 & 5 & 4.82 & 1 & .43 & -2.22 & 4.30 \\
\hline$d$ & $\begin{array}{l}\text { The opportunity for children to express their } \\
\text { feelings }\end{array}$ & 524 & 1 & 5 & 4.76 & 2 & .47 & -2.18 & 7.83 \\
\hline e & $\begin{array}{l}\text { The opportunity for children to think in their } \\
\text { own way }\end{array}$ & 524 & 2 & 5 & 4.75 & 3 & .48 & -1.79 & 3.04 \\
\hline$f$ & $\begin{array}{l}\text { Preschool teachers' acceptance of the chil- } \\
\text { dren's perspectives }\end{array}$ & 524 & 3 & 5 & 4.63 & 4 & .56 & -1.20 & .47 \\
\hline $\mathrm{g}$ & Encouraging children to exercise self-control & 524 & 2 & 5 & 4.47 & 5 & .71 & -1.35 & 1.66 \\
\hline a & The preschool teacher's personality & 524 & 2 & 5 & 4.42 & 6 & .66 & -.82 & .11 \\
\hline k & $\begin{array}{l}\text { The opportunity for children to choose (e.g., } \\
\text { toys, materials, seats, etc.) }\end{array}$ & 524 & 2 & 5 & 4.41 & 7.5 & .71 & -1.13 & 1.18 \\
\hline 0 & Preschool teachers' skills, qualifications & 524 & 1 & 5 & 4.41 & 7.5 & .74 & -1.08 & .72 \\
\hline j & $\begin{array}{l}\text { The opportunity for children to participate in } \\
\text { learning }\end{array}$ & 524 & 2 & 5 & 4.40 & 9 & .77 & -1.17 & .83 \\
\hline $\mathrm{b}$ & Preschool teachers' values and beliefs & 524 & 2 & 5 & 4.37 & 10 & .67 & -.72 & -.10 \\
\hline $\mathrm{h}$ & $\begin{array}{l}\text { The higher level of the preschool teacher's } \\
\text { own autonomy }\end{array}$ & 524 & 2 & 5 & 4.35 & 11 & .79 & -.89 & -.24 \\
\hline r & The number of children in the group & 524 & 1 & 5 & 4.00 & 12 & 1.17 & -1.04 & .17 \\
\hline $\mathrm{m}$ & $\begin{array}{l}\text { A kindergarten support structure that is } \\
\text { sensitive to the problems and wishes of the } \\
\text { children }\end{array}$ & 524 & 1 & 5 & 3.90 & 13 & .90 & -.42 & -.41 \\
\hline$q$ & Cultural rules & 524 & 1 & 5 & 3.81 & 14 & .87 & -.37 & -.42 \\
\hline $\mathrm{n}$ & Educational attainment of the children & 524 & 1 & 5 & 3.76 & 15 & .98 & -.57 & -.01 \\
\hline $\mathrm{p}$ & Social expectations & 524 & 1 & 5 & 3.45 & 16 & .95 & -.46 & .09 \\
\hline I & $\begin{array}{l}\text { The opportunity for children to decide (e.g., } \\
\text { what they will eat, whether they will sleep, } \\
\text { etc.) }\end{array}$ & 524 & 1 & 5 & 3.25 & 17 & 1.13 & -.02 & -.80 \\
\hline $\mathrm{i}$ & $\begin{array}{l}\text { The preschool teacher's non-disrupting teach- } \\
\text { ing style }\end{array}$ & 524 & 1 & 5 & 2.96 & 18 & 1.21 & -.13 & -.85 \\
\hline
\end{tabular}

A total of 524 preschool teachers evaluated the degree to which they agree with the above factors of fostering the autonomy of children by expressing their agreement on a 5-point scale from 1 to 5 , with 1 indicating that they disagree and 5 that they completely agree. Most of the preschool teachers agreed with the assertion that preschool teachers' positive attitude towards fostering the autonomy of children $(M=4.82)$ is a factor in fostering the autonomy of children. The lowest standard deviation was also found in the positive attitude towards fostering 
the autonomy of children $(S D=.43)$, while rather high values of asymmetry and kurtosis $(S K=-2.22$ and $K=4.30)$ indicated a greater number of higher values. The lowest level of agreement was with the assertion that a non-disrupting teaching style $(M=2.96)$ is a factor in fostering the autonomy of children. It was in response to this assertion that the answers of the preschool teachers showed the greatest difference $(S D=1.21)$, being near normally distributed $(S K=-.13, K=$ $.85)$. This may have resulted from the less understandable expression of the factor, causing the teachers to grade the assertion randomly. A more appropriate expression would be a democratic style of teaching. The preschool teachers expressed quite a high level of agreement with most of the factors of fostering the autonomy of children. Knowing the factors of fostering the autonomy of children is the key to autonomous preschool teachers fostering, improving and implementing the theory of fostering the autonomy of children in practice. In order to foster children's autonomy, it is important that preschool teachers have a positive attitude in the adoption of this theory (Walsh \& Gardner, 2006) and possess relevant expertise, skills, methods and experience (Morrow \& Richards, 1996).

The preschool teachers mainly agreed that children having an opportunity to decide what they will eat and whether they want to sleep is a factor of fostering children's autonomy $(M=3.25)$. However, as in the assertion that a non-disrupting teaching style is a factor in fostering the autonomy of children, the teachers' answers differed substantially $(S D=1.13)$ and were distributed near normally. In order to foster children's autonomy, they need to be given more decision-making opportunities, such as deciding whether or not they are hungry or sleepy. We checked the distribution of this variable with the coefficient of asymmetry, which can be asymmetric to the right or positive asymmetry (if the value of the coefficient is greater than zero), symmetric or normal distribution (if the value of the coefficient is zero), or asymmetric to the left or negative asymmetry (if the value of the coefficient is less than zero). With the coefficient of flattening, we verify that the variable is conical (if the coefficient value is greater than o), normal (if the coefficient value is o), or flattened (if the value of the coefficient is less than o). A coefficient value of more than 0.8 indicates a lot of flattening, or abnormal flattening. Where the negative values of $\mathrm{KA}$ are less than o, the asymmetry is to the left or negative asymmetry. Negative values of KS below -.80 show a lot of flattening, or abnormal flattening (the distribution is less sharp, the top is more straightforward and has shorter beets).

In free answers, the preschool teachers cited several factors as key factors in fostering children's autonomy: knowledge of the child's development, flexibility and perceptions of the preschool teachers, participation of parents and preschool teachers, etc. (37.4\%); ensuring choices, participation, expressing feelings, 
children's educational attainment (11.07\%); professionalism and training of preschool teachers $(5.73 \%)$; the autonomy of the preschool teacher $(4.59 \%)$; the positive attitude of the preschool teacher towards children and their independence (4.01\%); the preschool teacher's personality (4.01\%); the preschool teacher's ability to empathise (3.24\%); respect and acceptance of children (3.24\%); the example of the preschool teacher and his or her behaviour (3.24\%); and clearly set boundaries and rules and daily routine, trust in the child, education of the preschool teacher, fewer children in the group (less than $3 \%$ ).

The conditions for fostering children's autonomy must be met. We present the evaluation of Slovenian preschool teachers regarding the conditions for fostering the autonomy of children.

\section{Table 3}

Conditions for fostering the autonomy of children, in the opinion of preschool teachers

\begin{tabular}{|c|c|c|c|c|c|c|c|c|c|}
\hline & Factors of autonomy & $\mathrm{N}$ & Min & Max & M & $\mathbf{R}$ & SD & SK & K \\
\hline b & Authorisation and fostering of thinking & 524 & 1 & 5 & 4.70 & 1 & .55 & -1.67 & 1.86 \\
\hline $\mathrm{i}$ & $\begin{array}{l}\text { Children have the opportunity to solve prob- } \\
\text { lems }\end{array}$ & 524 & 1 & 5 & 4.65 & 2 & .56 & -1.40 & .98 \\
\hline c & Authorisation and fostering of feelings & 524 & 1 & 5 & 4.64 & 3.5 & .59 & -1.46 & 1.36 \\
\hline I & Providing incentives to children & 524 & 1 & 5 & 4.64 & 3.5 & .60 & -1.59 & 1.89 \\
\hline g & Supporting children's self-initiative & 524 & 1 & 5 & 4.56 & 5 & .72 & -1.64 & 2.18 \\
\hline $\mathrm{m}$ & Responding to questions from children & 524 & 1 & 5 & 4.51 & 6 & .76 & -1.85 & 4.30 \\
\hline $\mathrm{n}$ & Making realistic statements to children & 524 & 1 & 5 & 4.47 & 7 & .71 & -1.20 & .98 \\
\hline k & The autonomy of preschool teachers & 524 & 1 & 5 & 4.45 & 8 & .70 & -1.36 & 2.73 \\
\hline j & $\begin{array}{l}\text { Preschool teachers provide feedback and } \\
\text { rationale for children }\end{array}$ & 524 & 1 & 5 & 4.42 & 9 & .72 & -.84 & -.63 \\
\hline $\mathrm{h}$ & $\begin{array}{l}\text { Children have the opportunity to make deci- } \\
\text { sions }\end{array}$ & 524 & 1 & 5 & 4.41 & 10 & .73 & -.97 & .09 \\
\hline a & Accepting the perspective of children & 524 & 1 & 5 & 4.22 & 11 & .77 & -.68 & -.19 \\
\hline e & Encouraging children to exercise self-control & 524 & 1 & 5 & 4.19 & 12 & .93 & -1.34 & 2.06 \\
\hline$d$ & Authorisation and fostering of behaviour & 524 & 1 & 5 & 3.90 & 13 & .90 & -.29 & -.74 \\
\hline$f$ & $\begin{array}{l}\text { The preschool teacher's command communi- } \\
\text { cation }\end{array}$ & 524 & 1 & 5 & 1.97 & 14 & 1.01 & .83 & .05 \\
\hline
\end{tabular}

The preschool teachers $(N=524)$ evaluated the degree to which they agree with the above conditions for fostering the autonomy of children by expressing their agreement on a 5-point scale from 1 to 5, with 1 indicating that they disagree and 5 that they completely agree. The preschool teachers strongly 
agreed that allowing and encouraging the child's thinking was a condition for fostering the autonomy of children $(M=4.70)$. At the same time, they agreed that authorising and encouraging children to behave like children was a condition for fostering the autonomy of children $(M=3.90)$. The differences in the answers were rather small $(S D=.55$ and .56$)$, while the values of the coefficients of asymmetry $(S K=-1.67$ and -1.40$)$ and kurtosis $(S K=-1.67$ and .98$)$ positioned in the interval $(-2.0,2.0)$ allowed the assumption that the distribution is near normal.

The child's behaviour should not, of course, be detrimental to the child him or herself or to the others in the group. The condition for fostering children's autonomy is to allow the child's (innocent) behaviour as a way of encouraging him or her to find his or her own way of solving a problem (Reeve, 2009). The preschool teacher's command communication is not a condition for fostering the autonomy of children. The preschool teacher's communication with the child must be decisive, so that the child has the possibility of choice and reflection (Assor et al., 2002; Reeve, 2009, 2015). The greatest deviation in the responses occurred in condition $\mathrm{f}$ ) the preschool teachers' command communication $(S D=1.0)$. Similar to the previous reported variables with a higher standard deviation, the coefficients of asymmetry and kurtosis were small (SK $=.83$ and $K=.05$ ), indicating near normal distribution of the assessment of assertion $\mathrm{f}$ ) the preschool teachers' command communication.

We check the distribution of the variable with the coefficient of asymmetry. In this case, the KA values are greater than 0.20 , which means a lot of asymmetries. Negative values of KA indicate a large asymmetry to the left. The coefficient of flattening tells us whether the variable is point-sensitive (if the value of the coefficient is greater than o), normal (if the coefficient value is o) or flattened (if the coefficient value is less than o). KS values above o.8o show a lot or abnormal flattening.

\section{The impact of the assessment of both factors and conditions on the actual condition of fostering the autonomy of preschool children}

Analysis of the main components above the variables of the factors of autonomy of preschool teachers (Table 1) brought three factors explaining a total of $62.5 \%$ of the variance. The first factor, which we named qualification and job satisfaction (Table 1 , variables b, $\mathrm{d}, \mathrm{e}, \mathrm{f}$ ) explains $24.9 \%$ of the variance. This includes the professional qualifications of the preschool teachers and their satisfaction at work, as the professional qualifications of preschool teachers are a prerequisite for their autonomy. Moreover, the satisfaction of educators at work influences their motivation and professional autonomy (Van Gelderen, 2010). The second factor, 
which we named the systemic, legal factors of autonomy and the climate of the kindergarten (Table 2, the variables $g$, h, i, j, k) explains $24.5 \%$ of the variance. It concerns the fact that autonomy is enabled within legal regulations, as it is conditioned by the curriculum, the system vision and instrumental procedural autonomy (Iordőchescu, 2013), legislation (The Organisation and Financing of Education Act, 2007; The Preschools Act, 2005) and the kindergarten climate, which varies from one kindergarten to another and affects the behaviour of each member of the kindergarten (Hoy \& Miskel, 1996; Kim et al., 2009). The third factor explains $13.0 \%$ of the variance and was named the "hidden" factors of autonomy (Table 1, variables a and c). It covers the effects of national culture and subjective theories of preschool teachers (Dweck et al., 1995; Turnšek, 2013). Different cultures (societies) differentiate the individual's autonomy differently (Rudy et al., 2007), thereby encouraging autonomy to a greater or lesser extent. The prevailing values of society or the social context also affect preschool teachers and their way of teaching (Downie et al., 2004; Taylor et al., 2009).

In the opinion of the preschool teachers surveyed, $60 \%$ of the total variance is explained by the four factors of the model of factors of fostering children's autonomy. The first factor, which we named the didactic factor of fostering the autonomy of children (Table 2, variables $d, e, f, g, h, j$ ) explains $21.9 \%$ of the variance. This includes the behaviour of preschool teachers that fosters the autonomy of children. At work, the preschool teacher must follow the principles of the process and development model of planning, which includes two-way communication between the child and the preschool teacher; the self-inflicting authority of the preschool teacher, which provides the child with security and acceptance, while at the same time encouraging him or her to become independent and, consequently, to deal with attachment to the preschool teacher; and the preschool teacher enabling the child to judge and learn about moral principles (Kroflič, 1997). In so doing, the preschool teacher must take into account the conditions for fostering the autonomy of children, including the adoption of a child's perspective; authorising and encouraging the child's thinking, feelings and behaviour; and encouraging the child's ability to exercise self-control or autonomous self-regulation (Reeve, 2009). The second factor, which we named the qualification of the preschool teacher and the cultural aspect of fostering the autonomy of children (Table 3 , variables $n, o, p, q)$ explains $14.4 \%$ of the variance. It relates to the professionalism and expertise of the preschool teacher, society's expectations, and the influence of culture. This contributes to a greater or lesser fostering of children's autonomy. Preschool teachers should be able to teach children how to take responsibility for their own learning (e.g., helping them to find their strong and weak areas, 
to set their own goals, to evaluate their own learning and progress) (Chang, 2007; Little et al., 2002; Spratt et.al., 2002). Additional professional education of preschool teachers and changes in the preschool teacher's practice affect not only the work of preschool teachers and their professional identity (Hargreaves, 1998; Palmer, 1997), but also the quality of their pedagogical work with children. The education of preschool teachers is one of the quality indicators in kindergarten (Marjanovič Umek et al., 2002). The third factor explains $12.9 \%$ of the variance and was named the preschool teacher as a person (Table 2, variables $a, b, c)$. It relates to the preschool teacher's values and beliefs, his or her personality, and his or her positive attitude towards work, which influences the preschool teacher's way of teaching. Fostering children's autonomy also has an impact on the preschool teacher's personal disposition (Van den Berghe et al., 2013). The fourth factor, which we named the child's choice, participation (Table 2, variables $\mathrm{k}, \mathrm{l}, \mathrm{m}$ ) explains $11.5 \%$ of the variance. It refers to opportunities for making decisions, choosing and participating. It is the preschool teacher's encouragement of the autonomy of the children with behaviours that support the learning and interests of children, such as listening, providing choices and opportunities, providing feedback with a meaningful rationale, providing incentives and advice, answering questions, and making realistic statements (Deci et al., 1996; Reeve \& Jang, 2006). From the child's perspective, a key element in fostering autonomy in children is when the preschool teacher provides a supportive structure, that is, leadership that is sensitive to the problems and wishes of the children (Vansteenkiste et al., 2012). A condition for the preschool teacher to foster the autonomy of the children is listening to them and taking their suggestions into account, providing them with opportunities to choose, understanding them and trusting their abilities, encouraging them to ask questions and think, etc. (Williams \& Deci, 1996).

In the opinion of the preschool teachers surveyed, the conditions for fostering the autonomy of children are composed of two factors, which explain $62.6 \%$ of the total variance. The first factor explains $38.8 \%$ of the variance and was named the participation of children and preschool teachers (Table 3 , variables $a, b, c, g, h, i, j, k)$. In the process of child-rearing and education, preschool teachers give the children an opportunity to make decisions and solve problems, they accept the children's perspective, allow and stimulate the children's thinking and expression of emotions, support the children's initiative, and provide feedback to the children (Deci et al., 1996; Reeve \& Jang, 2006; Williams \& Deci, 1996). For preschool teachers, their own autonomy ensures the adoption of such decisions and the possibility of enabling children to participate. The appropriate pedagogical communication of the preschool teacher 
in a clearly structured environment (clear rules) is a prerequisite for fostering the autonomy of children. The second factor explains $23.8 \%$ of the variance and was named positive preschool teachers' communication (Table 3 , variables $\mathrm{f}$, $\mathrm{n}, \mathrm{m}, \mathrm{l})$. It refers to the preschool teacher giving realistic statements to children, answering their questions, showing non-indicative communication, and providing incentives for children. In order to foster the autonomy of children, preschool teachers must ensure safe communication and encourage the children to share their thoughts, opinions, suggestions and views. Moreover, preschool teachers must listen carefully to the children and respond with realistic statements (Reeve, 2006), otherwise we can suppress positive communication and the children's willingness to cooperate.

The opinion of the preschool teachers surveyed about their work in the group and the fostering of childhood autonomy form a single factor that explains $51.5 \%$ of the total variance.

\section{Figure 1}

Model of the influence of factors and conditions on the actual autonomy of children

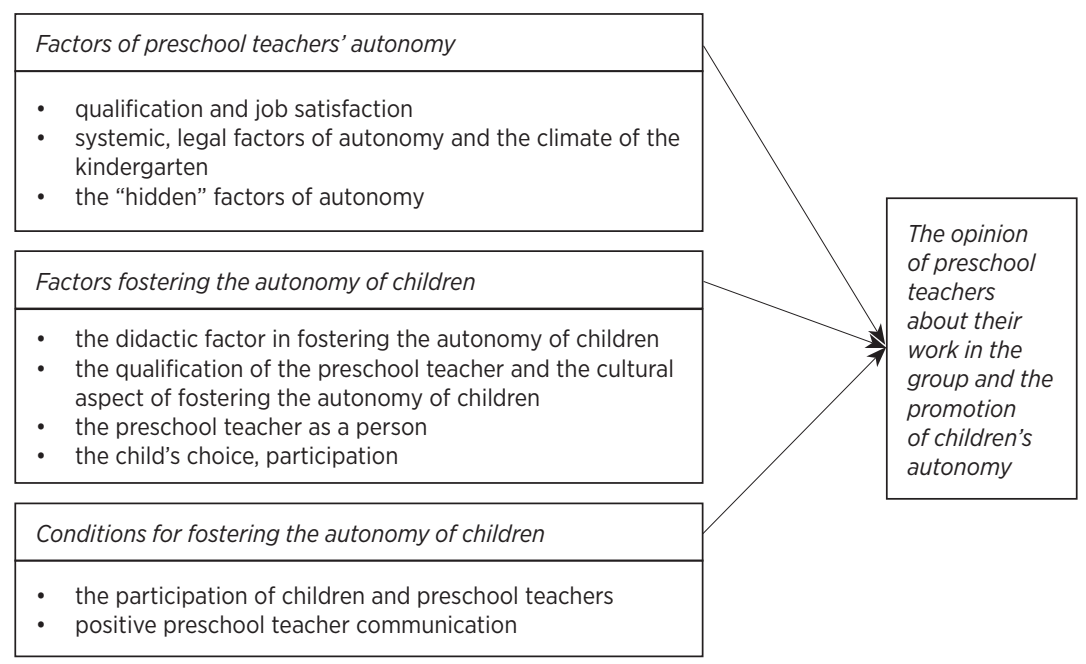

The model of the influence of the factors and conditions on actual child autonomy shown in Figure 1 was realised with a linear regression model in which the predictive variables of the above-presented dimensions (factors) of the factors and conditions of autonomy and the response variable are a uniform factor for assessing the actual autonomy of children. Linear regression is statistically significant (ANOVA, $p=.000$ ) and explains $36.8 \%$ of the total variance 
of the phenomenon (Adjusted R Square = .368). Variables with statistically significant coefficients explain more than one-third of the overall phenomenon.

\section{Table 4}

Calculation of the model of the influence of factors and conditions on the actual autonomy of children

\begin{tabular}{|c|c|c|c|c|c|}
\hline & B & Std. Er. & Beta & $\mathrm{t}$ & Sig. \\
\hline (Constant) & .000 & .035 & & .000 & 1.000 \\
\hline \multicolumn{6}{|l|}{ Factors of preschool teachers' autonomy } \\
\hline qualifications and job satisfaction & .002 & .037 & .002 & .059 & .953 \\
\hline $\begin{array}{l}\text { systemic, legal factors of autonomy and the climate of } \\
\text { the kindergarten }\end{array}$ & .023 & .040 & .023 & .579 & .563 \\
\hline "hidden" factors of autonomy & -.066 & .037 & -.066 & -1.792 & .074 \\
\hline \multicolumn{6}{|l|}{ Factors fostering the autonomy of children } \\
\hline $\begin{array}{l}\text { the didactic factor in fostering the autonomy of } \\
\text { children }\end{array}$ & .091 & .048 & .091 & 1.876 & .061 \\
\hline $\begin{array}{l}\text { the qualification of the preschool teacher and the } \\
\text { cultural aspect of fostering the autonomy of children }\end{array}$ & .081 & .040 & .081 & 2.057 & .040 \\
\hline the preschool teacher as a person & .133 & .041 & .133 & 3.261 & .001 \\
\hline the child's choice, participation & -.010 & .037 & -.010 & -.263 & .792 \\
\hline \multicolumn{6}{|l|}{ Conditions for fostering the autonomy of children } \\
\hline the participation of children and preschool teachers & .484 & .050 & .484 & 9.699 & .000 \\
\hline positive preschool teacher communication & -.022 & .037 & -.022 & -.579 & .563 \\
\hline
\end{tabular}

As can be seen from Table 4 above, no dimension of the factor of the autonomy of preschool teachers has a statistically significant influence on the estimation of the actual autonomy of children; therefore, sub-hypothesis $\mathrm{Ha}$ (The factors of preschool teachers' autonomy influence the actual fostering of children's autonomy) is discarded.

Statistical significance is shown by the coefficients of two variables of the concept factors of fostering the autonomy of children (Table 4, the variable preschool teacher's qualification and the cultural aspect of fostering the autonomy of children $(p=.040)$ and the preschool teacher as a person $(p=.001))$ and the coefficient of one variable of the concept conditions for fostering the autonomy of children (Table 4 , the variable child participation $(p=.000)$ ). Therefore, the subhypotheses $\mathrm{Hb}$ (The factors of fostering the autonomy of children affect the actual fostering of children's autonomy) and Hc (The conditions for fostering the autonomy of children affect the actual fostering of children's autonomy) are confirmed. 
The factors of the autonomy of preschool teachers have no influence on fostering the autonomy of children. This is in line with Nakata's findings (2011), which explain that being autonomous as a professional does not necessarily help preschool teachers to foster the autonomy of children. Many authors argue that there is a symbiotic relationship between the autonomy of children and the autonomy of preschool teachers, since fostering the autonomy of children depends on the autonomy of preschool teachers (Aoki, 2002; Benson, 2001; Kroflič, 2001; Nakata, 2009). However, based on our analysis, we agree with Nakata (2011) that, in order to foster the autonomy of children, it is not enough for preschool teachers to have professional autonomy; rather, preschool teachers must have an appropriate attitude towards this concept (Iordăchescu, 2013; Roth \& Weinstock, 2013) and must possess the expertise and methods by which they can encourage children to be autonomous (Castle, 2004; Reeve \& Yang, 2006).

Of the two dimensions of the conditions for fostering autonomy in children, the first, the participation of children and preschool teachers, demonstrates an effect by taking the perspective of children, supporting children's self-initiative, enabling children to make decisions and solve problems, allowing and encouraging the child's thinking and expression of feelings, sharing information with children, and encouraging the autonomy of the preschool teacher. Preschool teachers need autonomy to be able to judge professionally and decide upon and prepare the learning process by giving children the opportunity to make decisions and solve problems, encouraging them to think and allowing them to express their feelings. In order to foster the autonomy of children, non-indicative communication is needed (Reeve, 2009), enabling children to decide and think. Providing incentives for children, using realistic statements and preschool teacher responses (Reeve \& Yang, 2006), encourages children to solve problems and find new solutions, which contributes to fostering their autonomy.

\section{Conclusion}

According to preschool teachers' evaluation of the factors of their own autonomy, we find that these factors have no impact on fostering children's autonomy. Being autonomous as an expert does not mean that preschool teachers will consequently foster autonomy in children. Certain authors mentioned in the theoretical starting points explain that there is a particular symbiotic relationship between the autonomy of children and the autonomy of preschool teachers, especially from the point of view of the preschool teachers' professional knowledge. In order to foster the autonomy of children, what is needed 
above all is a proper attitude of preschool teachers towards this concept and appropriate expertise. In the study, we found that the evaluated factors of fostering the autonomy of children affect the actual fostering of children's autonomy, and that the evaluated conditions for fostering the autonomy of children affect the actual fostering of children's autonomy. In addition to professional knowledge, appropriate beliefs of preschool teachers about the usefulness of the concept, and knowledge of the concept of fostering the autonomy of children, the actual fostering of childhood autonomy is crucial, and it is important that preschool teachers believe that this way of working in the process of childcare in kindergarten is indispensable. In order to foster the autonomy of children, which has many positive effects (greater motivation and self-confidence of children, learning of responsibility, academic success, etc.), appropriate circumstances are also needed (kindergarten climate, small groups of children, professional leadership of the kindergarten, social context), which are not in the overall domain of preschool teachers.

\section{References}

Aoki, N. (2002). Aspects of teacher autonomy: Capacity, freedom, and responsibility. In P. Benson \& S. Toogood (Eds.), Learner Autonomy 7: Challenges to research and practice. Authentik. Assor, A., Kaplan, H., \& Roth, G. (2002). Choice is good, but relevance is excellent: Autonomy enhancing and suppressing teacher behaviours predicting students' engagement in schoolwork. British Journal of Educational Psychology, 72(2), 261-278.

Barfield, A., Ashwell, T., Carroll, M., Collins, K., Cowie, N., Critchley, M., Head, E., Nix, M. ... Robertson, M. C. (2001). "Exploring and defining teacher autonomy”, presented at the Developing Autonomy, Proceedings of the College and University Educators, Conference, Shizuoka, Japan. Benson, P. (2001). Teaching and researching autonomy in language learning. Longman.

Castle, K. (2004). The meaning of autonomy in early childhood teacher education. The Journal of Early Childhood Teacher Education, 25(1), 3-10.

Castle, K. (2006). Autonomy through pedagogical research. Teaching and Teacher Education, 22(8), 1094-1103.

Chang, L. Y. H. (2007). The influence of group processes on learners' autonomous beliefs and behaviors. System, 35(3), 322-337.

Deci, E. L., Ryan, R. M., \& Williams, G. C. (1996). Need satisfaction and the self-regulation of learning. Learning and Individual Differences, 8(3), 165-183.

Downie, M., Koestner, R., El Geledi, S., \& Cree, K. (2004). The impact of cultural internalization and integration on well-being among tricultural individuals. Personality and Social Psychology Bulletin, 30(3), 305-314.

Dweck, C. S, Chiu, C. Y., \& Hong, Y. Y. (1995). Implicit theories and their role in judgements and 
reactions: A word from two perspectives. Psychological Inquiry, 6(4), 267-285.

Eurydice (2008). Šolska avtonomija v Evropi: Politike in ukrepi [School autonomy in Europe: Policies and measures]. Ministry of Education and Sport.

George, D., \& Mallery, M. (2010). SPSS for windows step by step: A simple guide and reference, 17.0 update (10 ${ }^{\text {th }}$ ed.) Boston, MA: Pearson.

Grolnick, W. S. (2001). Discussant's comments: Symposium on influences on children's motivation: New concepts and new findings. Presented at the Annual Meeting of the Society for Research in Child Development. Minneapolis, MN.

Hardre, P. L., \& Reeve, J. (2003). A motivational model of rural students' intentions to persist in, versus drop out of, high school. Journal of Educational Psychology, 95(2), 347-356.

Iftene, C. (2014). Educational systems' autonomy. Facts and analysis. Procedia-Social and Behavioral Sciences, 142, 47-53.

Iordăchescu, G. D. (2013). Socio-pedagogical Paradigm of teachers' educational autonomy competence (EAC). Procedia-Social and Behavioral Sciences, 76, 398-402.

Kalin, J. (2002). Ravnatelj in razrednik pred ogledalom novega profesionalizma [The head teacher and the class teacher in the mirror of new professionalism]. Sodobna pedagogika, 53(1), 150-166. Kim, Y. H., Stormont, M., \& Espinosa, L. (2009). Contributing factors to South Korean early childhood educators' strategies for addressing children's challenging behaviors. Journal of Early Intervention, 31(3), 227-249.

Koren, A. (2002). Pomen avtonomije $v$ šolskem sistemu [The concept of autonomy in the school system]. Šola za ravnatelje. http://www.fm-kp.si/zalozba/ISBN/961-6268-83-x/135-144.pdf Koren, A. (2006). Avtonomija in decentralizacija v izobraževanju: študija vidljivosti v slovenskem šolskem sistemu [Autonomy and decentralisation in education: A study of visibility in the Slovenian school system]. Faculty of Management.

Krek, J., \& Metljak, M. (eds.) (2011). Bela knjiga o vzgoji in izobraževanju v Republiki Sloveniji 2011 [White paper on education in the Republic of Slovenia]. Pedagoški inštitut.

Kroflič, B., Batistič Zorec, M., Cemič, A., Plestenjak, M., Turnšek, N., \& Vilič, I. (2002). Stališča vzgojiteljic in vzgojiteljev predšolskih otrok do kurikuluma za vrtce ter njihova usposobljenost za uvajanje sprememb. Raziskovalno poročilo - rezultati evalvacijske študije [Attitudes of preschool teachers towards the kindergarten curriculum and their competence to introduce change. Research report - results of an evaluation study]. Faculty of Education. http://www.mizs.gov.si/fileadmin/mizs. gov.si/pageuploads/podrocje/razvoj_solstva/evalvacija/20oo_I/Kroflic_Breda.pdf Kroflič, R. (1997). Med poslušnostjo in odgovornostjo (Procesno-razvojni model moralne vzgoje) [Between obedience and responsibility (the process-developmental model of moral education)]. VIJA.

Kroflič, R. (2001). Avtonomija ravnatelja in pedagoško vodenje institucije. Ravnatelj in šolska avtonomija: znanstveno - strokovni posvet [The autonomy of the head teacher and the pedagogical management of the institution. The autonomy of the head teacher and school: Scientific-professional consultation] (pp. 21-22). 
slovenistika.files.wordpress.com/2009/05/avtonomija-ravnatelja2.doc

Kurikulum za vrtce [Kindergarten curriculum]. (1999). Ministrstvo za šolstvo in šport, Urad Republike Slovenije za šolstvo.

Little, D. (1995). Learning as dialogue: The dependence of learner autonomy on teacher autonomy.

System, 23(2), 175-181.

Little, D. (2002). The European language portfolio: Structure, origins, implementation and challenges. Language Teaching, 35(3), 182-189.

Logaj, V. (2012). Šolske politike in prerazporejanje moči pri medsebojnem povezovanju srednjih šol [School policies and the redistribution of power in the interconnection of secondary schools] (Doctoral dissertation). Fakulteta za management Koper.

Manzi, C., Regalia, C., Pelucchi, S., \& Fincham, F. D. (2012). Documenting different domains of promotion of autonomy in families. Journal of Adolescence, 35(2), 289-298.

Marentič Požarnik, B., Kalin, J., Šteh, B., \& Valenčič Zuljan, M. (2005). Učitelji v prenovi - njihova strokovna avtonomija in odgovornost [Teachers in renewal - their professional autonomy and responsibility]. Znanstveni inštitut Filozofske fakultete.

Marjanovič Umek, L., Fekonja, U., Kavčič, T., \& Poljanšek, A. (Eds.) (2002). Kakovost v vrtcih [Quality in Kindergartens]. Znanstveni inštitut Filozofske fakultete.

Masouleh, N. S., \& Jooneghani, R. B. (2012). Autonomous learning: A teacher-less learning! Procedia-Social and Behavioral Sciences, 55, 835-842.

Meng, L., \& Ma, Q. (2015). Live as we choose: The role of autonomy support in facilitating intrinsic motivation. International Journal of Psychophysiology, 98(3), 441-447.

Mooney, A., \& Blackburn, T. (2002). Children's views on childcare quality. Institute of Education, for DfES.

Morrow, V., \& Richards, M. (1996). The ethics of social research with children: An overview. Children and Society, 10(2), 90-105.

Nakata, Y. (2009). Towards learner autonomy and teacher autonomy in the Japanese school context.

In F. Kajik, P. Voller, N. Aoki, \& Y. Nakata (Eds.), Mapping the terrain of learner autonomy: Learning environments, learning communities and identities (pp. 190-213). Tampere University Press.

Nakata, Y. (2011). Teacher's readiness for fostering learner autonomy: A study of Japanese EFL high school teachers. Teaching and Teacher Education, 27(5), 900-910.

Noormohammadi, S. (2014). Teacher reflection and its relation to teacher efficacy and autonomy. Procedia-Social and Behavioral Sciences, 98(1), 1380-1389.

Öztürk, I. H. (2012). Teacher's role and autonomy in instructional planning: The case of secondary school history teachers with regard to the preparation and implementation of annual instructional plans. Educational Sciences: Theory \& Practice, 12(1), 295-299.

Palmer, P. J. (1997). The heart of a teacher. Identity and integrity in teaching. Change, 29(6), 14-22. Parrott, M. Y., \& Da Ros - Voseles, D. A. (2013). A picturesque view of dispositions, autonomy, and efficacy during the educational preparation of early childhood educators. Northeastern State University. http://www.eric.ed.gov/PDFS/ED540356.pdf 
Pelletier, L. G., Sequine-Levesque, C. S., \& Legault, L. (2002). Pressure from above and pressure from below as determinants of teachers motivation and teaching behavior. Journal of Educational Psychology, 94(1), 186-196.

Reeve, J. (1998). Autonomy support as an interpersonal motivating style: Is it teachable?

Contemporary Educational Psychology, 23(3), 312-330.

Reeve, J. (2006). Teachers as facilitators: What autonomy-supportive teachers do and why their students benefit. Elementary School Journal, 106(3), 225-236.

Reeve, J. (2009). Why teachers adopt a controlling motivating style toward students and how they can become more autonomy supportive. Educational Psychologist, 44(3), 159-175.

Reeve, J. (2015). Autonomy-supportive teaching: What it is, how to do it. In J. C. K. Wang, W. C. Liu \& R. M. Ryan (Eds.), Motivation in educational research: Translating theory into classroom practice, (pp. 129 - 152). Springer.

Reeve, J., \& Jang, H. (2006). What teachers say and do to support students' autonomy during a learning activity. Journal of Educational Psychology, 98(1), 209-218.

Reeve, J., Jang, H., Carrell, D., Jeon, S., \& Barch, J. (2004). Enhancing students' engagement by increasing teachers' autonomy support. Motivation and Emotion, 28(2), 147-169.

Reinders, H., \& Balcikanli, C. (2011). Learning to foster autonomy: The role of teacher education materials. Studies in Self-Access Learning Journal, 2(1), 15-25.

Roth, G., \& Weinstock, M. (2013). Teachers' epistemological beliefs as an antecedent of autonomysupportive teaching. Motivation and Emotion, 37(3), 402-412.

Rudy, D., Sheldon, K. M., Awong, T., \& Tan, H. H. (2007). Autonomy, culture, and well-being: The benefits of inclusive autonomy. Journal of Research in Personality, 41(5), 983-1007.

Rutar Ilc, Z. (1999). Avtonomija in ideologija [Autonomy and ideology]. Vzgoja in izobraževanje, $30(5), 16-17$.

Skinner, E. A., \& Belmont, M. J. (1993). Motivation in the classroom: Reciprocal effects of teacher behavior and student engagement across the school year. Journal of Educational Psychology, 85(4), 571-581.

Smith, R. C. \& Barfield, A. (2001). Interconnections: Learner autonomy, teacher autonomy. Learning, $8(1) 5-6$.

Spratt, M., Humphreys, G., \& Chan, V. (2002). Autonomy and motivation: Which comes first? Language Teaching Research, 6(3), 245-266.

Statistični urad RS [Statistical Office of the Republic of Slovenia]. http://www.stat.si/StatWeb/News/ Index/5916

Su, Y., \& Reeve, J. (2011). A meta-analysis of the effectiveness of intervention programs designed to support autonomy. Educational Psychology Review, 23(1), 159-188.

Tašner, V., Žveglič Mihelič, M., \& Mencin Čeplak, M. (2017). Gender in the teaching profession: University students views of teaching as a career. Center for Educational Policy Studies Journal, 7(2), 47-69.

Taylor, I. M, Ntoumanis, N., \& Smith, B. (2009). The social context as a determinant of teacher 
motivational strategies in physical education. Psychology of Sport and Exercise, 10(2) 235-243.

Thavenius, C. (1999). Teacher autonomy for learner autonomy. In S. Cotterall, D. Crabbe (Eds.), Learner Autonomy in Language Learning: Defining the Field and Effecting Chang (pp. 159-163). Peter Lang.

Tehrani, I. A., \& Mansor, W. F. A. W. (2012). The influence of 'teacher autonomy in obtaining knowledge' on 'class practice'. Procedia-Social and Behavioral Sciences, 66, 544-554.

Trnavčevič, A., \& Zupanc Grom, R. (200o). Marketing v izobraževanju [Marketing in education]. School for Head Teachers.

Tucker, C. M., Zayco, R. A., Herman, K. C., Reinke, W. M., \& Trujillo, M. (2002). Teacher and child variables as predictors of academic engagement among low-income African American children. Psychology in the Schools, 39(4), 477-488.

Turnšek, N. (2013). Subjektivne teorije o otroštvu in vzgoji [Subjective theories of childhood and education]. Pedagoška fakulteta UL.

Usma Wilches, J. (2009). Teacher autonomy: A critical review of the research and concept beyond applied linguistics. Íkala, 12(1), 245-275.

Van den Berghe, L., Soenens, B., Vansteenkiste, M., Aelterman, N., Cardon, G., Tallir, I. B., \& Haerens, L. (2013). Observed need-supportive and need-thwarting teaching behavior in physical education: Do teachers' motivational orientations matter? Psychology of Sport \& Exercise, 14(5), $650-661$.

Van Gelderen, M. (2010). Autonomy as the guiding aim of entrepreneurship education. Education + Training, 52(8), 710-721.

Vansteenkiste, M., Sierens, E., Goossens, L., Soenens, B., Dochy, F., Mouratidis, A., Aelterman, N., Haerens, L., \& Beyers, W. (2012). Identifying configurations of perceived teacher autonomy support and structure: Associations with self-regulated learning, motivation and problem behavior. Learning and Instruction, 22(6), 431-439.

Vula, E., Berisha, F., \& Saqipi, B. (2015). Introducing teacher mentoring in Kosovo schools - Potential and challenges for sustainability. Center for Educational Policy Studies Journal, 5(4), 109-124.

Vuk, S., Tacol, T., \& Vogrinc, J. (2015). Adoption of the creative process according to the immersive method. Center for Educational Policy Studies Journal, 5(3), 51-71.

Walsh, G., \& Gardner, J. (2006). Teachers' readiness to embrace change in the early years of schooling: A Northern Ireland perspective. European Early Childhood Education Research Journal, 14(2), 127-140.

Wellborn, J., Connell, J., Skinner, E., \& Pierson, L. (1992). Teacher as social context (TASC). Rochester, NY: University of Rochester.

Williams, G. C., \& Deci, E. L. (1996). Internalization of biopsychosocial values by medical students: A test of self-determination theory. Journal of Personality and Social Psychology, 7o(4), 767-779. http:// www.selfdeterminationtheory.org/questionnaires/10-questionnaires/82

Woolfolk, A. E., \& Hoy, W. K. (1990). Prospective teachers' sense of efficacy and beliefs about control. Journal of Educational Psychology, 82(1), 81-91. 
Zakon o organizaciji in financiranju vzgoje in izobraževanja /ZOFVI/ [Organisation and Financing of Education Act] $(1996,2007)$. Official Gazette of the Republic of Slovenia, No. 12/96, 16/2007. Zakon o vrtcih /Zvrt/ [Kindergartens Act]. (1996, 2005). Official Gazette of the Republic of Slovenia, No. 12/96, 100/2005, 62/2010-ZUPJS.

Zgaga, P. (1990). Razkroj 'Vodilne Ideologije' in rekompozicija teorije šole [The decomposition of 'leading ideologies' and the recomposition of the theory of school]. In D. E. Bahovec, Z. Kodelja \& P. Zgaga (Eds.), Teorija vzgoje: moderna ali postmoderna? Šolsko polje 3 (pp. 78-88). Univerza v Ljubljani.

Zupančič, J. (2013). Razmislek o razsežnostih avtonomije ravnateljev v slovenski osnovni šoli [Reflection on the dimensions of the head teacher's autonomy in the Slovenian primary school]. Vodenje v vzgoji in izobraževanju, 11(1), 117-131.

\section{Biographical note}

Tatjana Devjak, PhD in pedagogical science, employed at the Faculty of Education, University of Ljubljana, is an assistant professor of educational theory and associate professor for preschool education. She received her $\mathrm{PhD}$ in the field of ethical and civic education. She is the author of books, textbooks, manuals, workbooks, and scientific and professional contributions in the field of education, ethical, civic and preschool education in journals, monographs and other publications at home and abroad. She is a member of the Board for evaluation and quality and the member of the Commission for an elementary school in the Expert Council of Republic Slovenia for General Education. Since 2005 she leads lead various ESF projects.

Irena Janžekovič Žmauc, PhD, works at Slovenian Traffic Safety Agency in the field of prevention and education of safety on roads. Her work includes preparing materials, didactic contents for pupils in schools and kindergarten children, consulting the road traffic education and guiding projects. In her doctoral dissertation was her main research theme on Preschool teachers' attitudes towards their professional autonomy and toward promoting children's autonomy in kindergartens.

JožE BENČINA, PhD, is an associate professor in the field of economics and management in public sector at University of Ljubljana, Faculty of Administration and the head of the Department of Economic and Management in Public Administration. His main research interests include quality of governance, well-being and development indicators, and efficiency analyses. 